\title{
Reading Psalm 23 in African context
}

Author:
David T. Adamo ${ }^{1}$
Affiliation:
'Department of Biblical and
Ancient Studies, University of
South Africa, South Africa
Corresponding author:
David Adamo,
adamodt@yahoo.com
Dates:
Received: 25 July 2017
Accepted: 19 Oct. 2017
Published: 16 Apr. 2018
mobile device
to read online.
How to cite this article:
Adamo, D.T., 2018, 'Reading
Psalm 23 in African context',
Verbum et Ecclesia $39(1)$,
a1783. https://doi.
org/10.4102/ve.v39i1.1783
Copyright:
C 2018. The Authors.
Licensee: AOSIS. This work
is licensed under the
Creative Commons
Attribution License.

The book of Psalms is the best known, most discussed and most cited book of the Old Testament. Psalm 23 especially is the most loved book of the Psalms. That must have been the reason why it was named 'an American icon' and the 'nightingale of the Psalms'. Two major ways of reading this Psalm are: as a shepherd to a sheep and as God to a human. The author of this article reads Psalms 23 Africentrically, that is, as God to a human. This means that Psalms 23 is read for the purpose of protection, provision, healing and success in all aspects of life, which are the main concerns of African people. It means reading Psalm 23 existentially with African life interest.

Intradisciplinary and/or interdisciplinary implications: This article is concerned with biblical studies, African Traditional Religion and culture and African Biblical Hermeneutics. It seeks to challenge the traditional Eurocentric approaches for its methodological approaches that do not make biblical studies adequately relevant to African Christianity. The book of Psalms is used as a perfect example of how it can be interpreted relevantly in Africa. Further implication is that there will be reduction of the Bible and Christianity looking like a foreign book and religion.

\section{Introduction}

DeClaisse-Walford, Jacobson and Tanner (2014:238) ask the question: 'Has any psalm occasioned the spilling of more ink than Psalm 23?'. The book of Psalms no doubt stands out because it is the best known, most discussed and most cited book of the Old Testament in the history of reception (Botha 2015:283-300; Kennedy 1984:14-21; Merrill 1965:354-360; Morgenstern 1946:13-24). Undoubtedly, Psalm 23 appears to be one of the most familiar Psalms in the Bible (Crenshaw 2001:61) because 'Everyone knows Psalm 23' according to McCann (2008:42). That is also the reason why it was labelled 'an American icon' by Holladay (1993:359). Someone also labels it the 'nightingale of the Psalms' (Segal 2013:103). Despite its smallness, it has filled the whole world with 'melodious joy' (Segal 2013:103).

Various commentators gave Psalm 23 different themes. While according to Mays (1994:14) the theme is 'The Lord Is My Shepherd', Segal (2013:103) sees it as 'With Me'. Kraus (1988:302-305) thinks it is 'Security in the Goodness and Mercy of Yahweh', Schaefer (2001:58) 'You are with me' and Bullock (2015:166) 'The LORD Is My Shepherd, I lack Nothing'. Waltke and Houston (2010:416) titled it 'The Good Shepherd'. Watts (1984:395-406) calls it 'Psalm of Trust, Thanksgiving, and Praise'. All these titles are appropriate for Psalm 23 because they all reflect the content of Psalm 23.

I agree with Segal who says that there are two ways of reading Psalm 23, that is, 'As a shepherd to a sheep' and 'As God to a human' (Segal 2013:104). However, Africentric ${ }^{1}$ approach reads more as God to a human.

The fact is that many current Western scholars and even African biblical scholars are not very familiar with the Africentric approach to the book of Psalms. The purpose of this article is to present an Africentric approach to Psalms 23 not for the purpose of abandoning current Western interpretation or to say that the Africentric approach is the only authentic approach as far as African scholars are concerned. It is my opinion that the current Western scholarship can be beneficial to Africentric reading. In light of this, a review of the current Western interpretation of Psalm 23 will be done first before discussing the Africentric interpretation.

\section{Current Western interpretation of Psalm 23}

Its wide and rich imagery and metaphorical language which express a wide range of human emotion are superb. Psalm 23 opens with a very powerful metaphor: 'The Lord is my shepherd'.

1.Africentric is preferred to Afrocentric because the name of the continent is Afri-ca and not Afro-ca. 
A simple definition of a metaphor is 'using something to be something else which is obviously and literally not' (Mays 1994:112-119). It does not describe by comparison but only identifies by equation (Mays 1994:115-119). Psalm 23 has one of the most powerful animal metaphors in the Bible. Its imagery is classified as mammal and pastoral metaphors (Foreman 2011) and belongs to the category of postural metaphors. Although Tappy (1995:255-269) thinks that it lacks any historical allusion to the event, I strongly believe that Psalm 23 reflects many traditions in the Old Testament texts. The imagery of Yahweh as a shepherd reflected many biblical traditions, the Exodus journey from Egypt (Ex 15:13, Ps 77:21; 78:52-53) (Botha 2015:283-300), the prophetic promises of the exile and the return from exile to Jerusalem (Botha 2015:283-300). From the few instances of texts mentioned above, it appears that the author of Psalm 23 is very familiar with biblical traditions and tries to connect with other portions and stories of the history of ancient Israel in order to make use of them (Botha 2015:283-300; Bullock 2015:169). However, one tends to agree with many scholars that Psalm 23 probably originated from the late exile in Babylonia and was later recited in the postexilic setting.

The structure of Psalm 23 looks like this:

- The Lord is my Shepherd (1-4).

- The Lord as a Host (5-6). Shepherd is a title that is synonymous with a king. This is a powerful metaphor and it is used as a polemic argument that the vocation of a king is protection, guidance, care and even substituting one's life for the people (Botha 2015:283-300).

The imagery of shepherd-sheep appears clearly in verses 1-3. The sheep is a symbol of absolute loyalty and reliance on Yahweh. The sheep always abides in the sheepfold and surrender themselves to be governed by the shepherd (Brueggemann \& Bellinger 2014:123). The shepherd willingly provides for the sheep green grass, safe and secure water, and a safe, protected path. Botha (2015:283-300) sees Psalm 23 as a life story of the individual and guidance on the road of life.

Goulder sees national overtones in Psalm 23 because it has expressions which have national overtones. It is more likely that the singer is a national leader of ancient Israel, possibly a king (Goulder 2006:463-473). It is clear that the motif of trust is dominant. Goldingay (2006:334-355) says it is a 'psalm of trust'. Concerning the form and setting of Psalm 23, many scholars believe that the extreme personal tone of the Psalm makes it seem not to fit a royal and national use. While Merrill accept an individual person in a worship service within a circle of a family or clan, others disagree and consider it a royal Psalm when one considers Yahweh as a king and a great shepherd and the psalmist becomes a vassal to that king (Merrill 1965:354-360; Tanner 2004:270-283).

\section{Literary analysis of Psalm 23}

It is gratifying that the condition of the text is excellent with a clear picture of the meter (Kraus 1988:304). The meters present in this powerful short text are $3+2$ in vss. $2 b, 3 a, 3 b, 4 a, 5 a, 5 b, 6 a$ and $6 b$. In verse $1 b$ and $2 a, 3+3$ meter is present. At the conclusion of verse 4 is $2+2+2$ meter (Kraus 1988:304). Kohler maintains that Psalms 23 is a continuously uniform hymn with one single picture of a shepherd.

Psalm 23 is divided into three parts and three basic images by Weiser: shepherds in verses 1-2, the wanderer in verses 3-4 and the host in verses 5-6 (Weiser 1998:226-231; Clifford 2002:130). The structure is mainly determined by its successive image of God as a shepherd (1-4) and host (5) and also its successive pronoun used for Yahweh, that is, 'he' in verses 1-3, 'you' in verses 4-6 (Clifford 2002:130). The chapter's turning point is in the middle of verse 4 . Because of the psalmist's experience of being safely protected, guided (1-3), he or she has no choice but to forget about the fear of any evil, but to trust Yahweh who is the divine shepherd even in the midst of the worst imaginable dangers - because Yahweh is with the psalmist - 'you are with me'. In verse 5 there is a change in the image of God to a host who is honouring a guest and serving a meal. The conclusive verse functions like verse 4 because of experiencing the care. The response there is that 'goodness and mercy shall follow me'.

Even though Psalm 23 is a form of individual lament, it has a strong communal dimension. This can be seen in its allusion to Exodus traditions, especially a new Exodus with a new march through the wilderness, a new covenant and a new settlement in the land (Clifford 2002:130). This Psalm employs a tradition such as in Psalm 78:43-55 where the divine shepherd led the people of God from Egypt to the holy land 'he led out his people like sheep and guided them in the wilderness like a flock. He led them to safety so that they were not afraid' (Ps 78:52-53a). In Psalm 23, there is a skilful interplay of individual and communal elements where the idea of Yahweh is my shepherd as well as a shepherd of the people is written.

\section{The setting of Psalm 23}

If we consider verse $6 \mathrm{~b}$ according to Masoretic Text (MT), the singer appears to be a singer involved in the cult that has experienced extraordinary blessings. That is why he left the sanctuary trusting God and making a vow. Several other suggestions have been put forward, as a king in the house of worship, a priest or the representative of a sublime cultic mysticism. However, a closer look at verse 6 shows that the person has enemies and Yahweh provides a meal. Mowinckel (1979:167) thinks that the situation is the banquet at a sacrifice of thanksgiving. This Psalm seems to belong to the tradition of Jerusalem and can probably be dated in the pre-exilic time (Kraus 1988:306). 
Based on the current Western interpretation, Psalm 23 is classified as a Psalm of Confidence or Trust (Brueggemann 1984:154). Brueggemann (1984:123) also sees it as one of the 'Psalms of New Orientation. The Psalm has a grip on deep biblical and genuine spirituality. It describes a life of trustful receptivity of God's gifts (Brueggemann 1984:154). The author uses pronouns and names like several other Psalms, and the presence of God transforms everything. According to Kraus (1988:305), this Psalm belongs to the form of prayer songs which Gunkel considers as songs of trust (Clifford 2002:130-133). The form of the laments of the individual or personal lament is recognisable (Clifford 2002:130).

In the ancient Near Eastern context, a shepherd represents authority and care exercised by a deity (e.g. Marcum) or a king who represents these gods. In the Babylonian hymn to Marduk, Marduk cares for the weak as a benevolent shepherd (Hilber 2013:26). An Egyptian god also praises the sun god as the 'Brave Protector who tends his flocks' (Hilber 2013:26). King Hammurabi (1750 Before the Christian Era [BCE]) believed that his kingship originated from the gods and that he fulfilled his royal duty as a shepherd by providing 'pastures' and water to the people by settling them in a peaceful place (Hilber 2013:26). Assurbanipal (650 BCE) also declared that he had been appointed to overthrow his enemies (Adamo 2015a:1-13). This image of a shepherd does not only imply protection but also the authority to rule. The allusion to the divine shepherd is an important one as the concept symbolically represents God. There is a similarity between Psalm 23 and the African (Egyptian) poem, Admonition of Ipuwer, probably written during the 17th century BCE. For the psalmist in Psalm 23, there is only one shepherd, Yahweh.

It is important to note that the poem is describing a certain journey that ends in Jerusalem at the temple; therefore, the pilgrimage to Jerusalem may have formed the background to the superb imagery in Psalm 23 (Smith 1988:61-66).

\section{Africentric interpretation of Psalm 23}

It has been stated that one of the basic characteristics of African Biblical Hermeneutics (ABH) is that it is highly existential in its interpretation (Adamo 2015b:31-52). African biblical interpreters bring real-life interest into the text and it plays a major role in such interpretation. Such life interest may be healing, provision, success and protection, which are the major concerns of Africans. When African biblical interpreters approach the text, the main question is what does the text has to offer and not what is the historical, social and literary dimension of the text (Adamo 2015b:31-52). In this case, in African context Psalm 23 is classified as a Psalm of protection, provision, healing and success and will be interpreted in that context.

The structure of Psalms 23 in the African context is classified according to African real-life interest and what it can offer to the readers - protection, provision, healing and success. The division of Psalm 23 according to the protection, provision, healing and success based on the Africentric approach does not mean that protection, healing and success are alien or less important to the people of the Western world. Everybody in the world needs all these and is concerned. However, it is more critical in Africa because there is no certainty in almost everything. The lawlessness is indeed indescribable. Violence is rampant more than in the Western world. Whatever one does and wherever one goes, fear is pervasive. Thus Africentric structure of Psalm 23 is a complex one. Despite its complexity, I would like to suggest a structure or a rearrangement of Psalm 23 in African context or reading2:

1. Protection vss. $1 \mathrm{a}, 3 \mathrm{~b}, 4$, and $6 \mathrm{~b}$.

2. Provision vss.1b, 2, 5a \& c.

3. Healing vss. $3 a, 5 b$.

4. Success vs. 6 a.

\section{Protection}

The LORD is my shepherd (1a). ${ }^{3}$

He leadeth me in the paths of righteousness for his name's sake (3b).

Yea, though I walk through the valley of the shadow of death, I will fear no evil: for thou art with me; thy rod and thy staff they comfort me (4).

I will dwell in the house of the LORD for ever (6b).

\section{Provision}

I shall not want (1a)

He maketh me to lie down in green pastures

He leadeth me beside the still waters (2)

Thou preparest a table before mine in the presence of mine enemies (5a).

My cup runneth over (5c).

\section{Healing}

He restoreth my soul (3a).

Thou anointest my head with oil (5b).

\section{Success}

Surely goodness and mercy shall follow me all the days of my life (6a).

\section{Psalm for protection (Ps 23:1a, 3b, 4 and $6 b$ )}

The LORD is my shepherd (1a).

He leadeth me in the paths of righteousness for his name's sake (3b). Yea, though I walk through the valley of the shadow of death,

I will fear no evil: for thou art with me; thy rod and thy staff they comfort me (4).

I will dwell in the house of the LORD for ever (6b).

2.It does not mean that this author thinks that the canonical shape of the scripture is less important.

3.All translations are from the King James Version (KJV). 


\section{Protection in African indigenous system}

It is important to understand protection in African indigenous tradition in order to appreciate the Africentric reading of Psalm 23 as a protective Psalm.

All over the world, people are concerned with protection. In Africa especially, people are concerned with the destruction of crops, clothes, houses, land, water and protection against human beings, which is the most essential. The process of protection by African indigenous people is remarkably different from that of the Western world because of their peculiar perception of their worldview. The existence of evil, witches and sorcerers is painfully real. They use potent words (the so-called incantation), medicine like herbs and curses (called epe, isaasi, apeta, eedi) for defence. But during the advent of Christianity, Christians were asked to abandon these methods of protection. The converts then searched the Bible, which was the only instrument they had. Then they found the book of Psalms, whose words resemble their incantations. The Bible became a substitute.

\section{Psalm 23:1a, 3b, 4 and 6b}

It is important to recognise not only how the word shepherd (רעי) (vs. 1a) is used in the ancient world to refer to a king whose main responsibility is to protect and provide for the subject (Brueggeman \& Bellinger 2014:123) but also how it is used in Africa.

In Nigeria, there is an ethnic group in the northern part of Nigeria called the Fulani who traditionally are nomadic people tending cows with very few sheep. They drive and protect mainly cows with their stick or rod. Today, they face many problems because they have moved from their northern territory to the south where there are green pastures. Their cows eat farm crops and whoever bothers to challenge them will be molested or even killed without regret. I therefore think that the translation of the first sentence in Nigerian or African context is misleading because the shepherds in Africa, unlike ancient Israel, keep mostly cows and very few sheep. I suggest that it should be translated as keepers of cows. It is unfortunate that the Yoruba Bible translators translated it as Oluso Agutan (keepers of sheep) instead of Oluso maalu or oluso maalu and agutan (keepers of cows and sheep).

In verse $3 b$, the statement 'he leadeth me in the paths of righteousness for his name's sake' is as important as the verse 1a in African context. Like in Africa, the psalmist knows the power in name in ancient Israel. Yahweh guided, protected and provided for his people of Israel for 'his name's sake'. Leading, protecting and providing for his people for his name's sake is an important point that must be noticed. It means that God has done all of these according to his selfinterest or on behalf of his own reputation and according to his own nature (Bullock 2015). It means that when God acts in his own best interest, it is in Israel's interest also.
This is an expression that reflects name theology. As names are so important in African tradition, so also it is in ancient Israel. Names mean the totality of what a person is, including his or her power, character and honour. Traditional Africans do not bear names that do not have meanings. That is why traditional African names are celebrated in childhood during a 'naming ceremony', especially among the Yoruba people of Nigeria. It is believed that whatever type of name or meaning that is given to a child, that child will eventually grow to become. It is therefore important to discuss briefly African name system, particularly, among the Yoruba people of Nigeria. The most common names among the Yoruba can be classified as theophoric names. As in ancient Israel, such names have the appellation of God added to them. These theophoric names have deep theological meanings and can further be classified as prayer or request names (Oluwayiopese God will provide), appreciation or gratitude names (Tobi or Oluwatobi-God is great) and acknowledgment names (Oluwa segun - God is victorious). There are other names that have to do with the circumstances in which a child is born. There is an expectation that each child will live up to the meanings of those names. I believe that the implication of the above names is that Africans, particularly the Yoruba people of Nigeria, will be in a better position to understand 'for his name's sake' in Psalm 23 than the Euro-American people. Yahweh decides to protect his people 'for his name's sake', that is, his nature, his holy character, his power and all that Yahweh is.

Verse 4 talks about walking through the valley of the shadow of death without fear of evil.

In verse 4 , 'the valley of the shadow of death' poses some difficulties because the Hebrew word צלמות, which is a compound noun, seems to me a very deep shadow or total darkness (Craigie 1983:207). It is not only part of the metaphor of the shepherd but is also associated with the Exodus and the wandering through the deep shadow of the wilderness where no one seems to be sure of their existence. It may be used deliberately by the psalmist to convey the threat of death as it is done in Job 10:21-22. The psalmist's confidence rests on the assurance that even in the shadow of death he has no reason to be afraid of death because he is in the midst of God's presence, protection and provision (Craigie 1983:207). It does not mean that enemies are not present, but God's presence and companionship will prevent them from hurting the psalmist.

In verse 4 , the phrase 'for thou art with me' is also an important one. This is the psalmist's recognition of the presence of God and possibly represented by the staff and rod. This reminds one of the promise 'I am with you' to Jacob (Gn 28:15), to Jeremiah (Jr 1.8, 19), to Judah (Jr. 15:20; $30: 11 ; 42: 11 ; 46: 28$ ), to Isaiah (Isa. 41:10; 43:5) and to Hagai (Hag. 11:13; 2:4). This forms the assurance for the psalmist and that is why he will fear no evil even in the middle of a crisis. This appears to be the central theme.

Most unfortunately, travelling on most Nigerian roads is like walking through the valley of the shadow of death 
because of kidnappers on the roads. Almost every day one hears that somebody is killed by armed robbers or the Fulani herdsmen or kidnappers who demand ransom. An example is a fearful road from Anyigba town to Okene in Kogi State, where I lecture. No one seems to be safe when travelling on that road. It is like travelling in the valley of the shadow of death.

In African tradition and religion, especially among the Yoruba people of Nigeria, the belief is that everyone has an enemy, seen or unseen. These enemies are witches, wizards and sorcerers who are regarded as the main sources of evil. They are always around to wreak havoc. Like Africans, the psalmist was aware of the terrible havoc that the enemy can cause. This havoc is painfully real in Africa. Primate Ayelabola states the confession of a witch as evidence of African reality as reported by Dopamu (1987):

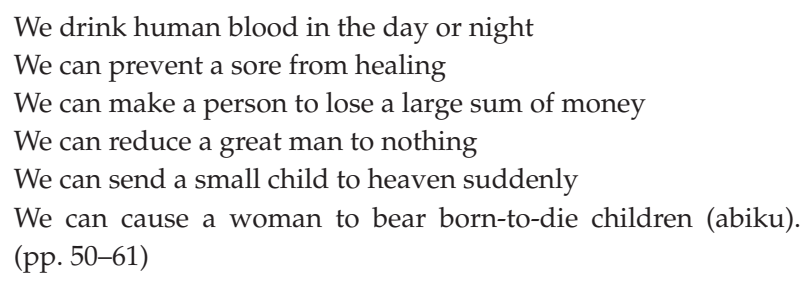

The assurance of the Lord's presence is the rod and the staff. This imagery can be best understood by many African herdsmen who use them for real defence and protection. The chiefs also have rods and staff as a symbol of possession of power. Among the Yoruba people of Nigeria, it is called opa. This opa performs different functions. It is used for defence or support for an old man to prevent them from falling. It is also used as a symbol of authority and power because it may have magical power for protection. These various uses of staff and rod will enable Africans to understand Psalm 23 better.

As Yahweh guides, protects and provides for his people in the wilderness journey for his name's sake, not because of their goodness but his mercy, so also African readers of Psalm 23 believe and affirm the fact that Yahweh is ready to guide, provide and protect the readers of this passage as they sing, memorise, chant, recite and write Psalm 23 on parchments, doorposts, motor vehicles or even bodies.

Psalm 23:6b mentions dwelling forever in the house of Yahweh. This imagery calls to mind what happened in Mesopotamia where true worshippers dedicated statues in the temple of their gods to symbolise the individual continuous presence before their god that would guarantee divine safety, peace and goodness. This resembles the theology of inviolability of Jerusalem during the period of the prophet Jeremiah when the temple symbolised safety for the people of Israel. The people of Israel thought that as long as the temple stood in Jerusalem and the name of Yahweh is in the temple and the city, the city would not be destroyed.
Thus, every worshipper longed to be in the temple. Certainly, the psalmist was aware of this symbol of protection in the house of the Lord when he says, 'I will dwell in the house of the LORD forever'.

In fact, in African indigenous churches, Psalm 23:1a, 3b, 4 and $6 \mathrm{~b}$ is a protective and performative Psalm that can be chanted, written on parchments and worn on the waist, arm or neck or hung on motor vehicles as a talisman. In other words, the inscription is 'worn' as a symbol of protection and it represents the presence of the Almighty God. Therefore, it is believed that motor vehicles with this 'sign' are immune to accident, death, armed robbery and hijacking on the dangerous Nigerian roads where no one is actually sure of a safe trip to anywhere. Inscribing this sign or index, therefore, guarantees safety. This is equivalent to saying 'Yahweh is a match' for all of live's dangers. He is able to keep his own safe in his loving care. Just as pilgrims leave Jerusalem festival with the message of the potent promise, Yahweh's words, 'I will be with you', is not only for the heroes of faith like Moses, Joshua and Abraham but also for everyone who trusts in him and holds that promise. The Lord is their escort.

\section{Psalm for provision (Ps 23:1b, 2, $5 a$ and c)}

\author{
I shall not want (1a) \\ He maketh me to lie down in green pastures \\ He leadeth me beside the still waters (2) \\ Thou preparest a table before me in the presence of mine enemies ( $5 a$ ). \\ My cup runneth over (5c).

\section{Provision in African indigenous system}

In African tradition, the belief that a human being can work 24 hours without getting rich is common. The belief is that riches come from gods, divinities, ancestors and spirits. It is not unusual for people to approach the ancestors, the gods of the land, the divinities and the native priests who can make contact. It is also believed that there are some potent words (incantation) to recite after the contact with the gods, divinities, spirits and ancestors who will bring abundant riches. It is also still a common thing in Africa that one can use human being or part of human being to make money which comes from the ancestors or gods. Therefore, to have provision is not only hard work but also through the appeal to the gods. There are many examples of African potent words (so-called incantations) for provision (Adamo 2005):

$\begin{array}{ll}\text { Aluko ti o ni osun, ki rahun osun } & \begin{array}{l}\text { Aluko that owns osun does not } \\ \text { complain lack of osun }\end{array} \\ \text { Ori Agbe nigbe agbe de igbo oro } & \begin{array}{l}\text { The destiny of Agbe takes agbe } \\ \text { to the forest of aro }\end{array} \\ \text { Arira ma je ki nrahun owo } & \begin{array}{l}\text { Arira do not let me lack money } \\ \text { Arira ma je ki nrahun ola. }\end{array} \\ \begin{array}{l}\text { Arira do not let me lack riches. } \\ \text { (p. 92) }\end{array}\end{array}$

Aluko ti o ni osun, ki rahun osun Aluko that owns osun does not complain lack of osun to the forest of aro Arira do not let me lack riches. (p. 92) 
Another African potent words (incantations) for riches are (Adamo 2005):

$$
\begin{array}{ll}
\text { Ori mi o se rere fun mi } & \text { My destiny gives me fortune } \\
\text { Eleda mi o se rere fun mi } & \text { My creator gives me fortune } \\
\text { Ori oka ni saanu oka } & \begin{array}{l}
\text { Ok's destiny has mercy on oka } \\
\text { Ori ere ni saanu ere }
\end{array} \\
\begin{array}{l}
\text { The destiny of python has mercy on } \\
\text { python }
\end{array} \\
\text { Afomo ope ni saanu ope } & \begin{array}{l}
\text { Parasite of a palm tree has mercy on } \\
\text { a palm tree (p. 93c) }
\end{array}
\end{array}
$$

It is firmly believed that chanting, singing and writing the above potent words on parchments, doorposts, bodies and clothes will bring prosperity.

However, when converts possess the Bible, especially the Psalms, the words resemble that of the African potent words (incantations) for possession. This led to the belief that the book of Psalms is good for recitation in order to obtain possession miraculously. Such portions of Psalm 23 are Psalm $23: 1 b, 2,5 a$ and $c$.

\section{Psalm 23:1b, 2, 5a and c}

Some commentators translate vs. $1 \mathrm{~b}$ with the prominent Hebrew verb with the verb אחס with means 'I shall lack nothing' or 'I shall not lack' (Goulder 2006:463-473; Kraus 1988:302-305) which I think is a better translation. This same verb is used for Yahweh's provision for Israel in the desert in Deuteronomy 2:7:

For the LORD thy God hath blessed thee in the work of thy hand: he knoweth thy walking through this great wilderness: these forty years the LORD thy God hath been with thee; thou hast lacked nothing.

Unlike the Western people, the main concern for the majority of Africans is how to get daily bread because of the high level of poverty in Africa. To lack daily bread, clothes and general provision is a common thing in Africa. Therefore, this Psalm which concerns itself with not lacking anything is an important one to African life interest. As long as the shepherd guides, protects and leads, the psalmist cannot lack anything. That is the simple faith of the psalmist and the reason why African readers, scholars, chanters and singers inscribe these passages in parchments or doorposts expecting God to repeat the experience of the Exodus where the children of Israel experienced lacking nothing.

In Psalms 23:5, preparing a table or setting out food on a table as a gesture of hospitality is what Yahweh has done in the presence of enemies who had wished one to die of hunger or to overturn the motor vehicles on which this section of Psalm 23 is written. When this is read in conjunction with verse $1 \mathrm{~b}$ (lacking nothing), it means having the basic food and rest in life.

In verse $5 c$, 'my cup runneth over' is a sign of surplus and abundant provision. African Bible readers, chanters, singers and writers on parchments, on bodies or on vehicles believe that they will surely get needed provisions. Of course, that is why this section is classified as Psalm of provision. Psalm 23 is saying Yahweh does not only lead and protect, he also provides for his own.

\author{
Healing \\ He restoreth my soul ( $3 a)$. \\ Thou anointest my head with oil (5b).
}

\section{African indigenous therapeutic system}

African therapeutic system is different from the Western system. Unlike the World Health Organization's (WHO) definition of good health as the absence of disease or infirmity, the African definition has to do with the state of total physical, mental, social well-being as a result of maintenance of a good relationship and harmony with nature, divinities, spirits and fellow human beings. Lack of good health is in three categories: natural or physical, supernatural and mystical. Ways of treating diseases, therefore, involve natural medicine or herbs, consulting the gods or divinities or ancestors to resolve the supernatural and mystical problems. Some potent words (incantations) are also prescribed to drive away the evil powers or evil spirits. Below is the example of potent words for the cure of scorpion stings (Adamo 2005):

Oorun lode lalam wonu

When the sun rises, the female lizard disappears

Oorun kuju alaamu jade (7 times) When the sun sets, the female lizard appears. (7 times) (p. 52c)

Again all these were to be discarded at the point of becoming Christian converts without any concrete substitution, except the Bible. When Christians searched the scripture, they also found passages where people were healed by prayer, by potent words, by herbs and others. The book of Psalm and other Bible passages were chosen to replace the African potent words (incantations).

'Thou anointest my head with oil' has to do with the restorative power of life-giving oil. In Africa, oil is used for coronation. It is also used for new babies. Oil may be used for healing purposes, especially for wounds. Among the indigenous Yoruba people of Nigeria, oil is used to lower the high temperature and fever of a young child when applied to his or her head. That is why all new mothers are always in possession of native oil called adin in the Yoruba language. It is also used to protect the skin when it is rubbed on the body during harsh harmattan weather in Nigeria. To anoint one with oil is to honour the person. It is also to restore one to life and vigour. It is quite remarkable that in most African indigenous churches, prophets first of all anoint the oil and read a certain portion of Psalms before the healing.

In light of the African tradition and the content of this section of Psalm 23, African indigenous churches read this section of Psalm 23 therapeutically believing in the power of the word of God to heal more than their African incantations. 


\section{Psalm for Success (Ps 23:6a)}

Surely goodness and mercy shall follow me all the days of my life. (6a)

\section{Success in African indigenous system}

Success in African indigenous tradition involves having many wives and children, passing examination, good profit in business, going on a journey and safe return, securing an employment, success in court cases and many other things (Adamo 2005:90-95). If one fails in one of these aspects examination, promotion, having children or love relationship it is considered lack of success (Adamo 2005:90-95). For these reasons, many will go to any lengths to obtain medicine to enhance success in the above activities.

In the prayer for help, it is the enemies (Ps 7:5; 69:26; 71:11; 109:16) who pursue, but instead of the enemies pursuing, it is the 'goodness and mercy' of the Lord that pursue the psalmist. This is considered success in African understanding. When goodness and mercy pursue all the days of someone's life, it means lack of evil and failure in everything one does. It is the absence of life-threatening death or suffering. Even though the enemies are present, they are rendered harmless by the goodness and mercy of the Lord that is actively pursuing.

Psalms 9, 24, 46, 51, 119:9-16 and 134 are other examples of success Psalms (Adamo 2005:8-43).

In Nigeria, Psalm 23 is not only written on motor vehicles but is also written on parchments, on doors, on clothes, even on the body as a talisman. Thus, it is believed that if the Psalms are recited repeatedly, it means one is participating in the events that took place in the ancient biblical time. Reading, reciting and wearing of the portion of Psalms of protection is considered to be a prayer asking God to perform the miracle that happened to the original writer to be repeated in the present life. The recitation of this Psalms is the participation in ancient biblical events that may motivate God to repeat that miracle of protection, healing, provision and success.

\section{Conclusion}

There is a temptation for some scholars who are not familiar with the simple biblical faith of Africans to dismiss this Africentric interpretation as fetish and unscholarly, but a closer examination of the African context shows that care must be taken before dismissing the approach. The Africentric ways of classifying Psalm 23 into protective, therapeutic provision and success reflect African indigenous tradition and churches' use of Psalms, which has spread over most of the churches in Africa, particularly Nigeria.

This use of Psalms for protection, healing, provision and success may possibly reflect the way it was used in ancient
Israel as attested by archaeological discoveries of a handful of Phoenician and Punic amulets from the first millennium with the verbs שמר [guard] and נצר [protect] inscribed on them (Schmitz 2002:818-822; Smoak 2010:421-432, 2011:75-92). The presence of these two verbs in both West Semitic inscriptions and the book of Psalms indicates some common cultural and religious practices and common purpose for invoking the deity's protection or help (Smoak 2011:75-92). Inscribing words on metal and apotropaic magic in ancient Israel is not uncommon as was also uncovered by archaeologists (Smoak 2011:72-92). Several seventh to sixth-century Punic gold bands were discovered in the excavations at Carthage with the same two verbs (שמר guard and נצר protect) as part of the protective formula as those in these Psalms (Barnett \& Mendelsson 1987; Krahmalkov 2000:471-472; Smoak 2011:72-92).

African Christians read, sang, chanted and inscribed this Psalm with a view to be protected on a dangerous journey on the road or on a flight or sea or when one is asleep at night to be healed of diseases, for provision at the time of need and to achieve success in life. That is the existential situation in Africa.

Brown attested to the fact that Psalms are performative when used orally, chanted and recited as divine prayers by the Christian church as early as the third-century Christian Era (CE) not only for guidance but also to drive away demons (Brown 2014):

The performative, oral roots of many biblical psalms can be inferred from the dynamic language of the psalmic rhetoric and from ritual literature found throughout the ancient Near East which has greatly expanded our understanding of the possible use and setting. They were chanted, and sung on a regular basis by the early third century c.e. The dramatic rise of monasticism in the fourth century, moreover, gave the Psalms additional attention: ascetics recited and chanted the psalms as daily prayer not only for personal guidance but also for spiritual warfare against demons. Much of the early Christian exegesis was, in fact, aimed at enabling the clergy, particularly monks, to sing and recite the psalms. (pp. 7-8)

Like the ancient Israelites who were the original authors of the Psalter, many biblical scholars, including the author of this article and members of African indigenous churches, see the Psalter as divine, potent and performative. The words of Psalm 23 can be used to protect, heal diseases and bring about success in the same way as words of incantation (ogede) are used in Africa.

Apart from the archaeological finding mentioned above, a few eminent biblical scholars (E. Jacob, W. Eichrodt, O. Prockesh, G. von Rad, G.A.F. Knight and R. Bultmann) would probably agree with African biblical scholars that the spoken word in ancient Israel was 'never an empty sound but an operative reality whose action cannot be hindered once it has been pronounced' (Eichrodt 1967:69; Jacob 1958:127; Knight 1953:14-16; Von Rad 1965:85).

Those who recount Palm 23, and of course, some other specific Psalms, by writing, singing, chanting and wearing the words of this Psalm on their bodies take up the identity of ancient Israel who was the first receiver of God's miracles 
and actions. This brings out the possibility of receiving the same action of God in the history of healing, protection, provision and success.

The repetitive reading, chanting and writing on parchments, on motor vehicles and on doorposts means a reaffirmation of faith in Yahweh's power to save his people as he did with ancient Israel.

Reading Africentrically is a way of re-enacting God's dealing with ancient Israel and could be repeated even for the readers with transformation. As reading Psalms gives the psalmist the privilege of participating in the event of history, so also the Africentric reading of Psalm 23 gives readers or singers the privilege of participating in the event of history so many years ago.

Those who read, chanted and sang Psalm 23 Africentrically do not only take on the identity of those whose behalf God has acted in history but also receive the transformative power of God's words in the Psalms. This is the re-experience of God's salvation history. These reflect an elegant and enduring statement of faith in God to perform miracles as he has done in the time of Exodus. In other words, for African Christians Exodus is not just a historical event but a present reality.

In the words of Nasuti (2001:144):

One of the most important sources of the peculiar power of the Psalms lies in their ability to situate those who used them in a relationship with God because worshippers appropriate the words of the Psalms as if they were those Psalms first-person speakers.

This way of viewing Psalms resembles trends in modern literary theory, especially speech act theory (Nasuti 2001:144), which affirms that words are performative. Those who use these Psalms take on a certain role with regard to those narratives.

The Bible, particularly the Psalms, becomes the talisman or amulets, medicine, potent words (so-called incantations) for protection, healing, provision and enhancing success when inscribed on parchments, bodies, vehicles, doorposts and recited, chanted and sung with unwavering faith or trust in God.

Certainly, the sense of the entire Psalm 23 is a calm reassurance and abiding trust in God despite the reality of the threat of evil or even death. It is a declaration of how the God of Israel acts decisively to counter all circumstances.

\section{Acknowledgements Competing interests}

The author declares that he has no financial or personal relationships that may have inappropriately influenced him in writing this article.

\section{References}

Adamo, D.T., 2005, Reading and interpreting the Bible in African indigenous churches, Justice Jeco Press, Benin.
Adamo, D.T. 2015a, Semiotic interpretation of selected Psalms inscriptions on motor vehicles in Nigeria 7, 1-13, viewed 10 March 2017, from http://scriptura.journals.ac.za

Adamo, D.T., 2015b, 'The task and distinctiveness of African biblical hermeneutics', Old Testament Essays 28(1), 31-52. https://doi.org/10.17159/2312-3621/2015/v28n1a4

Barnett, R.D. \& Mendelssohn, C., 1987, Tharros: A catalogue of material in the British Museum from Phoenician and other tombs at Tharros, Sardinai, British Museum Publications, London.

Botha, P.J., 2015, 'Following the tracts of righteousness of Psalm 23', Old Testament Essays 28(2), 283-300. https://doi.org/10.17159/2312-3621/2015/V28N2A5

Brown, W., 2014, 'The Psalms: An overview', in W. Brown (ed.), The Oxford handbook of the Psalms, pp. 1-26, Oxford University Press, Oxford.

Brueggemann, W., 1984, The message of the Psalms: A theological commentary, Augsburg, Minneapolis, MN.

Brueggemann, W. \& Bellinger, W.H., Jr., 2014, Psalms, Cambridge University Press, Cambridge.

Bullock, C.H., 2015, Psalms, Teach the Text Commentary, Baker Books, Grand Rapids, MI. Clifford, R.J., 2002, Psalms 1-72, Abingdon Press, Nashville, TN.

Craigie, P.C., 1983, Psalms 1-50, Word Biblical Commentary, Word Publisher, Waco, TX. Crenshaw, J.L., 2001, The Psalms: An introduction, William B. Eerdmans, Grand Rapids, MI. DeClaisse-Walford, N., Jacobson, R.A. \& Tanner, B.L., 2014, The book of Psalms, William B. Eerdmans, Grand Rapids, MI.

Dopamu, A.P., 1987, 'The reality of Isaasi, Apeta, Ironsi and Efun as forces of evil among the Yoruba', Journal of Arabic and Religious Studies 4, 50-61.

Eichrodt, W., 1967, Theology of the Old Testament II, SCM Press, London.

Foreman, B.A., 2011, Animal metaphors and the people of Israel in the book of Jeremiah, Vandenhoeck and Ruprecht, Gottingen.

Goldingay, J., 2006, Psalms: Psalm 1-41, Baker Academic, Grand Rapids, MI.

Goulder, M., 2006, 'David and Yahweh in Psalms 23 and 24', Journal of the Study of Old Testament 30(3), 463-473. https://doi.org/10.1177/0309089206067467

Hilber, J., 2013, Psalms, Zondervan, Grand Rapids, MI.

Holladay, W.L., 1993, The Psalms through three thousand years: Prayer book of a cloud of witnesses, Fortress Press, Minneapolis, MN.

Jacob, E., 1958, Theology of the Old Testament, transl. A.W. Heathcote \& P.J. Allcock, Harper \& Row, New York.

Kennedy, J., 1984, 'Psalm 23, strong faith and quiet confidence', Theological Educator $28,14-21$.

Knight, G.A.F., 1953, A biblical approach to the doctrine of the trinity, T. \& T. Clark, Edinburgh.

Krahmalkov, C.R., 2000, Phoenician-Punic dictionary, Peetrers, Leuven, pp. 471-472. Kraus, H.J., 1988, Psalms 60-150, transl. H.C. Oswald, Augsburg, Minneapolis, MN. Mays, J.L., 1994, Psalms. Interpretation, Westminster/John Knox Press, Louisville, KY. McCann, C., Jr., 2008, 'Preaching the Psalms: Psalm 23', Journal for Preachers 31(2), 42-48. Merrill, A.L., 1965, 'Psalm XXIII and the Jerusalem tradition', Vetus Testamentum 85(3), 354-360. https://doi.org/10.1163/156853365X00224

Morgenstern, J., 1946, 'Psalm 23', Journal of Biblical Literature 65(1), 13-24. https:// doi.org/10.2307/3262214

Mowinckel, S, 1979, The Psalm in Israel's Worship 2 vols.; transl. D.R. Ap-Thomas; Nashville: Abingdon Press.

Nasuti, N.P., 2001, 'Historical narrative and identity in the Psalms', Horizon in Biblical Theology 23(2), 132-153. https://doi.org/10.1163/187122001X00071

Schaefer, K., 2001, Psalms, The Liturgical Press, Collegeville, PA.

Schmitz, P.C., 2002, 'Reconsidering Phoenician inscribed amulet from the vicinity of Tyre', Journal of the American Oriental Society 122, 817-822. https://doi. org $/ 10.2307 / 3217621$

Segal, B.J., 2013, A new Psalm, Green Publishing House, Jerusalem.

Smith, M.S., 1988, 'Setting and rhetoric in Psalm 23', Journal for the Study of Old Testament 41, 61-66. https://doi.org/10.1177/030908928801304104

Smoak, J.D., 2010, 'Amuletic inscriptions and the background of YHWH as guardian and protector in Psalm 12', Vetus Testamentum 60, 421-432. https://doi. org/10.1163/156853310X504856

Smoak, J.D., 2011, 'Prayers of petition in the Psalms and West Semitic inscribed amulets: Efficacious words in metal and prayers for protection in biblical literature', Journal for the Study of Old Testament 36(1), 75-92. https://doi. org/10.1177/0309089211419419

Tanner, B., 2004, 'King Yahweh as the good shepherd: Taking another look at the image of God in Psalm 23', in B.F. Batto \& K.L. Roberts (eds.), David and Zion: Biblical studies in Honor of J.J.M. Roberts, pp. 270-283, Eisenbrauns, Winona Lake, IN.

Tappy, R., 1995, 'Psalm 23: Symbolism and structure', Catholic Biblical Quarterly 57(2), 255-269.

Von Rad, G., 1965, Old Testament theology, II, T. \& T. Clark, Edinburgh.

Waltke, B.K. \& Houston, J.M., 2010, The Psalms as Christian worship, William B. Eerdmans, Grand Rapids, MI.

Watts, J.D., 1984, 'Psalms of trust, thanksgiving, and praise', Review and Expositor 81(3), 395-406. https://doi.org/10.1177/003463738408100305

Weiser, A., 1998, The Psalms, The Westminster Press, Philadelphia, PA. 